\title{
RANCANG BANGUN APLIKASI PENGENALAN HURUF \\ UNTUK ANAK USIA DINI BERBASIS ANDROID
}

\author{
Febri Bayu Prasetiyo ${ }^{1}$, Ridwan Yusuf., S.T, M.T.I ${ }^{2}$, M. Adie Syaputra, S. Kom., M.T.I ${ }^{3}$ \\ ${ }^{1}$ Program Studi Teknik Infomatika, STMIK Dharma Wacana Metro \\ ${ }^{2,3}$ Dosen Tetap Teknik Informatika, STMIK Dharma Wacana Metro \\ Jalan Kenanga No.3 Mulyojati Kota Metro \\ Email : febribayuprasetiyo10@gmail.com
}

\begin{abstract}
ABSTRAK
Pendidikan anak usia dini adalah suatu upaya pembinaan yang di tujukan kepada anak sejak lahir sampai dengan usia enam tahun. Program pendidikan anak usia dini harus di sesuaikan dengan kebutuhan minat dan perkembangan anak. Dalam era sekarang ini anak-anak usia dini sudah mulai belajar mengeja dan membaca. Hal ini sangat dipenting karena itu merupakan dasar kita untuk mengetahui suatu informasi. Namun, pada umumnya aplikasi pengenalan huruf hanya menggunakan gambar dan teks. Dengan fasilitas android diharapkan anak-anak dapat menangkap isi dari aplikasi yang dibangun.

Dalam era sekarang ini anak-anak usia dini sudah mulai belajar mengeja dan membaca. Hal ini sangat dipenting karena itu merupakan dasar kita untuk mengetahui suatu informasi. Namun, pada umumnya aplikasi pengenalan huruf hanya menggunakan gambar dan teks. Dengan fasilitas android diharapkan anak-anak dapat menangkap isi dari aplikasi yang dibangun.
\end{abstract}

Kata kunci: Pembelajaran Huruf, Smartphone Android, Usia Dini, Game Adventure, Game Anak-anak. 


\section{PENDAHULUAN}

\subsection{Latar Belakang}

Pendidikan anak usia dini adalah suatu upaya pembinaan yang di tujukan kepada anak sejak lahir sampai dengan usia enam tahun. Pendidikan anak usia dini harus di sesuaikan dengan kebutuhan minat dan perkembangan anak.

Saat ini siapa yang tidak kenal game diSmartphone Android? Hampir semua orang sudah mengenal jenis-jenis gamediSmartphone, dari kalangan anakanak hingga dewasa. Android Studio merupakan suatu aplikasi yang bisa digunakan untuk membuat suatu aplikasi yang dapat berfungsi pada perangkat Smartphone Android dengan jenis ekstensi APK

Dalam era sekarang ini anak-anak usia dini sudah mulai belajar mengeja dan membaca. Hal ini sangat dipenting karena itu merupakan dasar kita untuk mengetahui suatu informasi.Namun, pada umumnya aplikasi pengenalan huruf hanya menggunakan gambar dan teks. Dengan fasilitas android diharapkan anak-anak dapat menangkap isi dari aplikasi yang dibangun.

\subsection{Rumusan Masalah}

Berdasarkan latar belakang diatas, maka dapat ditarik rumusan masalah yaitu belum ada aplikasi pembelajaran huruf untuk usia dini menggunakan game adventure.

\section{LANDASAN TEORI}

\subsection{UML (Unified Modelling Language)}

\section{Unified Modelling Language} (UML) adalah sebuah "bahasa" yang telah menjadi standar dalam industri untuk visualisasi, merancang dan mendokumentasikan.

UML Menyediakan beberapa notasi dan artifak standar yang bisa digunakan sebagai alat komunikasi bagi para pelaku dalam proses analisa dan desain. Dalam proses analisa dan desain, ada tiga artifak yang penting yaitu Use CaseDiagram, Sequence Diagram dan Class Diagram beserta notasi yang terhubung dengannya. Use Case Diagram merupakan artifak dari prosesanalisa, Sequence Diagram dan Class Diagram merupakan artifak dari proses desain. UML mendefinisikan diagram-diagram berikut ini:

a. Use Case Diagram

Use case diagram menggambarkan fungsionalitas yang diharapkan dari sebuah sistem. Yang ditekankan adalah "apa" yang diperbuat sistem, dan bukan "bagaimana". Sebuah use case merepresentasikan sebuah interaksi antara aktor dengan sistem.

b. Activity Diagram 
1) Activity diagram menggambarkan berbagai alir aktivitas dalam sistem yang sedang dirancang, bagaimana masing-masing alir berawal, decision yang mungkin terjadi, dan bagaimana mereka berakhir. Activity diagram juga dapat menggambarkan proses paralel yang mungkin terjadi pada beber apa eksekusi.

2) Activity diagram merupakan state diagram khusus, yang sebagian besar state adalah action dan sebagian besar transisi di-trigger oleh selesainya state sebelumnya (internal processing). Oleh karena itu, activity diagram tidak menggambarkan perilaku internal sebuah sistem dan interaksi antar subsistem, tetapi lebih menggambarkan proses-proses dan jalur-jalur aktivitas dari level atas secara umum.

c. Class Diagram

1) Class adalah sebuah spesifikasi yang jika diinstansiasi akan menghasilkan sebuah objek dan merupakan inti dari pengembangan dan desain berorientasi objek. Class menggambarkan keadaan (atribut/properti) suatu sistem, sekaligus menawarkan layanan untuk memanipulasi keadaan tersebut (metoda/fungsi).

2) Class diagram menggambarkan struktur dan deskripsi class, package dan objek beserta hubungan satu sama lain seperti containment, pewarisan, asosiasi, dan lain-lain.

d. Sequence Diagram

Pengertian Sequence Diagram adalah salah satu dari diagram-diagram yang ada pada UML, sequence diagram secara grafis menggambarkan bagaimana objek berinteraksi antara satu sama lain melalui pesan pada sebuah use case atau operasi.

\section{METODE PENELITIAN}

\subsection{Kerangka Berfikir}

\section{Tabel 3.1 Kerangka Berfikir}

\begin{tabular}{|c|c|c|c|}
\hline No & Uraian Kegiatan & Proses & Sub Proses \\
\hline \multirow[t]{2}{*}{1} & \multirow[t]{2}{*}{ Perencanaan } & \multirow[t]{2}{*}{ Membuat Proposal } & Menetapkan Objek \\
\hline & & & $\begin{array}{l}\text { Menetapkan Metode yang } \\
\text { akan di gunakan }\end{array}$ \\
\hline \multirow[t]{2}{*}{2} & \multirow[t]{2}{*}{$\begin{array}{l}\text { Menerapkan } \\
\text { Metode }\end{array}$} & \multirow[t]{2}{*}{$\begin{array}{l}\text { Merencanakan alur } \\
\text { proses penelitian } \\
\text { berdasarkan metode }\end{array}$} & $\begin{array}{ll}\text { Mengumpulkan data } \\
\text { dengan cara } \\
>\quad \text { Studi Pustaka } \\
>\text { Observasi } \\
>\quad \text { Komunikasi } \\
\\
\text { atau } \\
\text { Wawancara }\end{array}$ \\
\hline & & & $\begin{array}{l}\text { Mengolah data dengan } \\
\text { cara } \\
\qquad \quad \text { Pengembanga } \\
\\
\text { n sistem } \\
\text { dengan } \\
\text { metode } \\
\text { Waterfall }\end{array}$ \\
\hline 3 & $\begin{array}{l}\text { Melaksanakan } \\
\text { penelitian }\end{array}$ & $\begin{array}{l}\text { Menerapkan hasil } \\
\text { perancangan }\end{array}$ & \\
\hline
\end{tabular}




\begin{tabular}{|l|l|l|l|}
\hline 4 & $\begin{array}{l}\text { Menarik } \\
\text { kesimpulan }\end{array}$ & & \\
\hline
\end{tabular}

\subsection{Alur Penyelesaian Masalah}

Proses alur penelitian ini menerangkan langkah-langkah dalam penyusunan tugas akhir mulai dari proses pengumpulan data hingga tahap presentasi tugas akhir. Metode penelitian tugas akhir ini dapat dilihat pada gambar 3.2 dibawah ini:

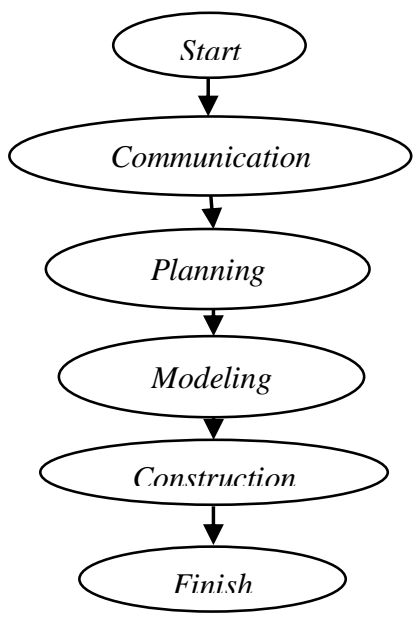

Gambar 3.1 Flowchart Metode Penelitian

a. Communication

Sangat diperlukan adanya komunikasi dengan anak usia dini dan guru demi memahami dan mencapai tujuan yang ingin dicapai. Penulis melakukan penelitian dan mengumpulkan datadata yang diperlukan anak usia dini.

b. Planning

Tahap ini berguna untuk mengetahui soal resiko yang dihadapi nanti, serta mengetahui apa saja sumber daya yang dibutuhkan, menghasilkan apa, serta yang paling penting adalah mengatur jadwal pembuatan perangkat lunak yang efektif.

\section{c. Modeling}

Pada tahap perancangan ini penulis merancang struktur data, tampilan interface dan tujuannya untuk lebih memahami gambaran besar dari apa yang akan dikerjakan.

\section{d. Construction}

Tahap ini penulis melakukan pengkodean bahasa yang dapat dibaca oleh mesin. Tujuannya untuk menemukan kesalahan yang mungkin terjadi untuk diperbaiki.

e. Finish

Tahapan Finish merupakan tahapan terakhir (finishing) dalam pembuatan aplikasi $\mathrm{ABCD}$ runner.

\subsection{Perangkat Keras dan Perangkat Lunak}

\subsection{Perangkat Keras}

1. Laptop dengan spesifikasi:

a. Prosesor 2,3 GHz Intel Core i5 Prosesor digunakan sebagai pusat atau otak dari kegiatan komputer dalam melakukan perhitungan dan menjalankan tugas input dan output. 
b. RAM 8 GB 1333 MHz DDR3 RAM

(Random Access Memory) merupakan perangkat kerasuntuk tempat menyimpan data yang diakses oleh Processor.Data yang ada di RAM bisa diakses secara acak dengankecepatan yang sama, sehingga di sebut Random (acak). Datayang tersimpan di RAM bersifat sementara, karena hanya akan ada jika ada listrik atau saat komputer menyala dan akan hilang jika komputer mati.

c. GEFORCE 740MB VGA (Video Graphic Adapter) merupakan bagian komputer,di dalam unit komputer yang berperan penting untukmenampilkan output proses ke layar monitor. Tanpa VGA,layar komputer tidak akan menampilkan apa-apa. VGA cardsendiri ada yang berupa slot tambahan (add on) ataupunbawaan produsen motherboard yang disebut dengan VGA onboard.

\section{d. Hardisk 500 GB SATA}

Harddisk adalah perangkat lunak yang berfungsi sebagai alat untuk menyimpan dan mengambil informasi digital yang ada pada sebuah unit komputer.

\subsection{Perangkat Lunak}

\subsubsection{Operating System}

Windows 7 Professional/Mac OS X Mavericks Operating System atau OS adalah perangkat lunak sistem yang bertugas untuk melakukan kontrol dan manajemen perangkat keras serta operasioperasi dasar sistem, termasuk menjalankan software aplikasi seperti Xampp, php, Mysql,dan HTML5.

\subsubsection{Adobe Photoshop}

Merupakan Perangkat lunak buatan Adobe Systems yang dikhususkan penciptanya untuk pengeditan foto/gambar. Perangkat lunak ini banyak di pakai oleh Desainer, fotografer, dan Perusahaan iklan sehingga seringkali dianggap sebagai perangkat lunak marketing paling bermanfaat di dunia entah itu di gunakan untuk desain banner,iklan,logo,baju,dll . Adobe Photoshop, bersamaAdobe Acrobat di klaim sebagai produk terbaik yang pernah diproduksi oleh Adobe Systems.

\section{HASIL DAN PEMBAHASAN}

\subsection{Communication (Komunikasi)}

Berdasarkan hasil wawancara, observasi, dan study pustaka maka didapat

\subsubsection{Analisis Sistem Saat Ini}

Sistem yang berjalan dalam game pembelajaran huruf (adventure) mempunyai kelemahan diantaranya sebagai berikut:

1. Data data yang berkaitan dengan game pembelajaran huruf (adventure) masih menggunakan gambar dan teks. 
4.1.2 Sistem yang akan digunakan

Perancangan yang penulis usulkan yaitu menggunakan metode game pembelajaran huruf (adventure) berorientasi objek meliputi: Use case diagram, dan Activity diagram. Dalam sistem yang diusul meliputi perancangan program dan struktur yang meliputi:

\subsubsection{Skenario}

\section{Deskripsi Aktor}

Aktor adalah abstraksi dari orang dan sistem yang mengaktifkan fungsi dari target sistem. Berdasarkan Use Case Diagram pada Gambar 4.1, deskripsi aktor dapat dilihat pada Tabel 4.4.

Tabel 4.1 Deskripsi Aktor

\begin{tabular}{|c|l|l|}
\hline No & \multicolumn{1}{|c|}{ Aktor } & \multicolumn{1}{c|}{ Deskripsi } \\
\hline 1. & Pengguna & $\begin{array}{l}\text { Aktor yang dapat berperan } \\
\text { menjalankan semua menu } \\
\text { yang ada, pada menu game } \\
\end{array}$ \\
& & \begin{tabular}{l} 
pengenalan huruf. \\
\hline
\end{tabular} \\
\hline
\end{tabular}

Tabel 4.2 Deskripsi Use Case

\begin{tabular}{|c|l|l|}
\hline No & \multicolumn{1}{|c|}{ Use Case } & \multicolumn{1}{c|}{ Deskripsi } \\
\hline 1. & $\begin{array}{l}\text { Memilih menu } \\
\text { Game }\end{array}$ & $\begin{array}{l}\text { Sistem digunakan oleh } \\
\text { pengguna untuk memilih } \\
\text { menu Game. }\end{array}$ \\
\hline 2. & Memainkan game & $\begin{array}{l}\text { Sistem digunakan oleh } \\
\text { pengguna untuk memainkan } \\
\text { game. }\end{array}$ \\
\hline
\end{tabular}

2. Skenario Use Case Menu Game

No Use Case: 01

Nama Use Case:Menu Game

Skenario :

Tabel 4.3 Skenario Use Case Menu Game

\begin{tabular}{|c|c|}
\hline Aktor & Reaksi Sistem \\
\hline \multicolumn{2}{|l|}{$\begin{array}{l}\text { 1. Memilih menu } \\
\text { game }\end{array}$} \\
\hline & $\begin{array}{l}\text { 2. Sistem } \\
\text { menampilkan } \\
\text { halaman menu } \\
\text { game }\end{array}$ \\
\hline \multicolumn{2}{|l|}{ 3. Memainkan game } \\
\hline & $\begin{array}{l}\text { 4. Sistem } \\
\text { menampilkan } \\
\text { halamangame }\end{array}$ \\
\hline
\end{tabular}

3. Skenario Use Case latihan game No Use Case: 02

Nama Use Case: latihan game Skenario :

Tabel 4.4 Skenario Use Case Latihan Game

\begin{tabular}{|c|c|}
\hline \multicolumn{1}{|c|}{ Aktor } & Reaksi Sistem \\
\hline 1. Memilih menu latihan & $\begin{array}{c}\text { 2. Sistem menampilkan } \\
\text { halaman latihan dan } \\
\text { memberi soal berupa voice }\end{array}$ \\
$\begin{array}{l}\text { 3. Menjawab soal latihan } \\
\text { jengan memilih }\end{array}$ & $\begin{array}{c}\text { Sistem menampilkan yang benar } \\
\text { halaman jawaban benar } \\
\text { atau salah dan melanjutkan } \\
\text { soal berikutnya }\end{array}$ \\
\hline
\end{tabular}


4. Skenario Use Case credits

No Use Case: 03

Nama Use Case: credits

Skenario :

Tabel 4.5 Skenario Use Case credits

\begin{tabular}{|c|c|}
\hline Aktor & Reaksi Sistem \\
\hline 1. Memilih credit game & \\
\hline & 2. Sistem \\
& menampilkan \\
& halaman \\
& creditberupa nama \\
& dan NPM penulis \\
\hline
\end{tabular}

\subsubsection{Use Case Diagram}

\section{Use CaseDiagram}

menggambarkan fungsi tertentu.

Aktor yang terlibat dalam aplikasi adalah user.

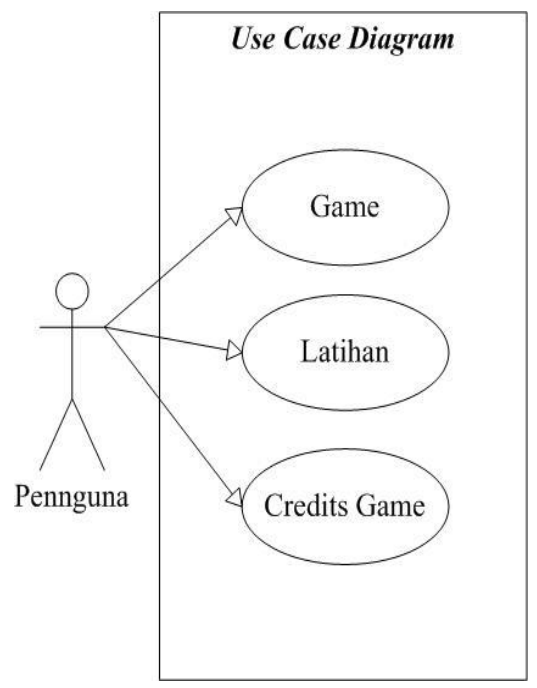

Gambar 4.1Use Case Diagram game

\subsubsection{Activity Diagram}

Activity diagram atau Diagram aktivitas merupakan diagram yang menggambarkan bagaimana alur aktivitas berjalan.

1. Activity diagram game

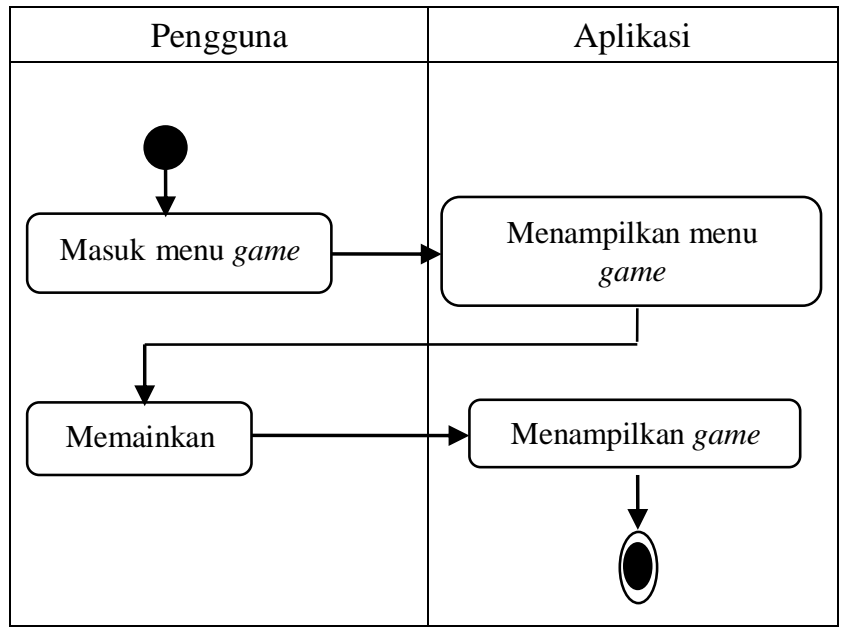

Gambar 4.2 Activity Diagram Game

2. Activity Diagram Latihan

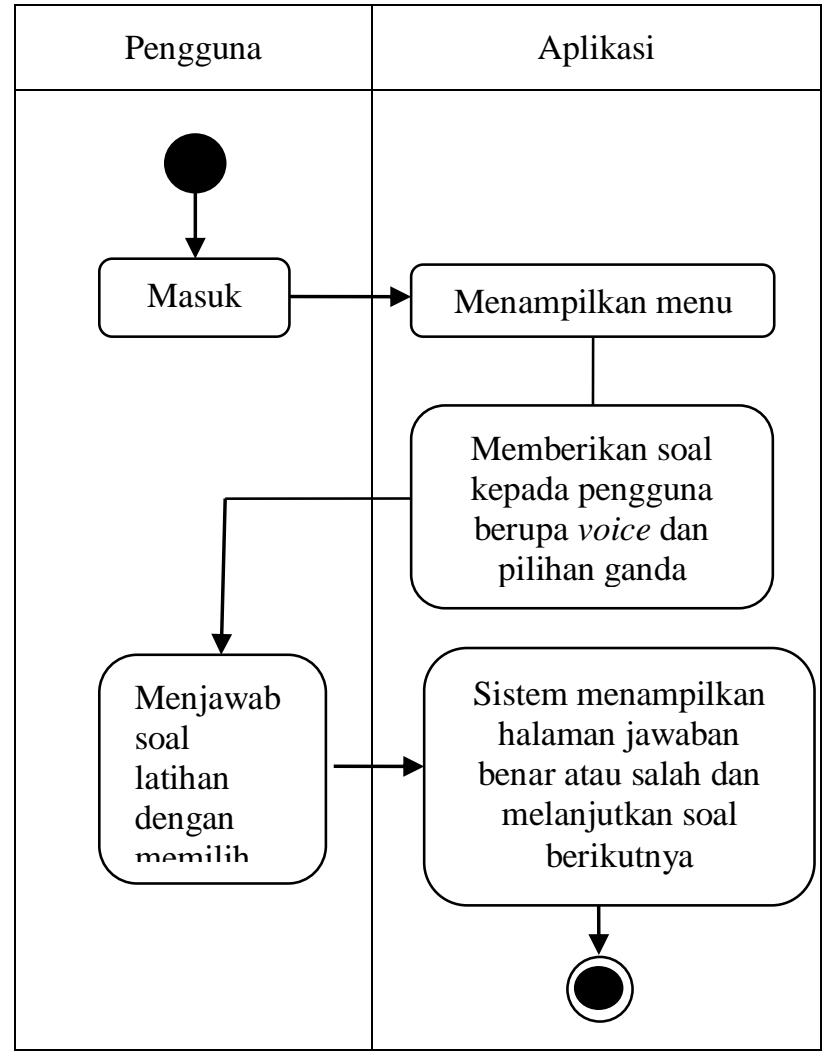

Gambar 4.3 Activity Diagram Latihan

\section{Activity Diagram Credits}

\begin{tabular}{|c|c|}
\hline Pengguna & Aplikasi \\
\hline
\end{tabular}




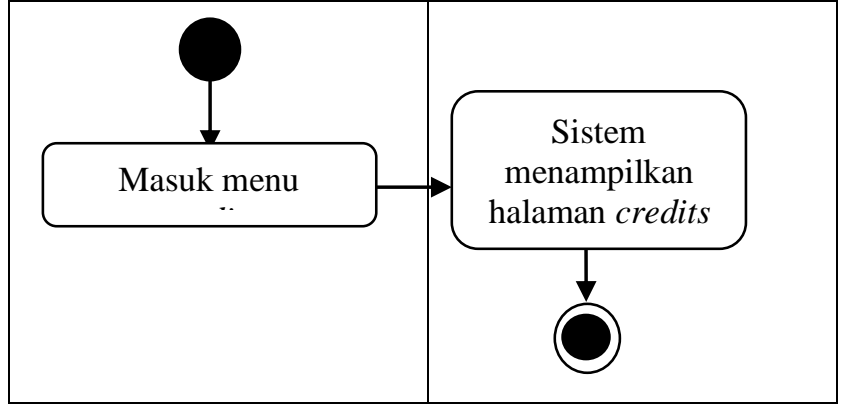

Gambar 4.4 Activity Diagram Credits

\subsubsection{Sequence Diagram}

Sequence Diagram merupakan suatu rancangan yang menunjukan urutan sementara dimanapesan-pesan dikirim diantara objek-objek untuk menyelesaikan pekerjaan tersebut.

\section{Sequence Diagram Game}

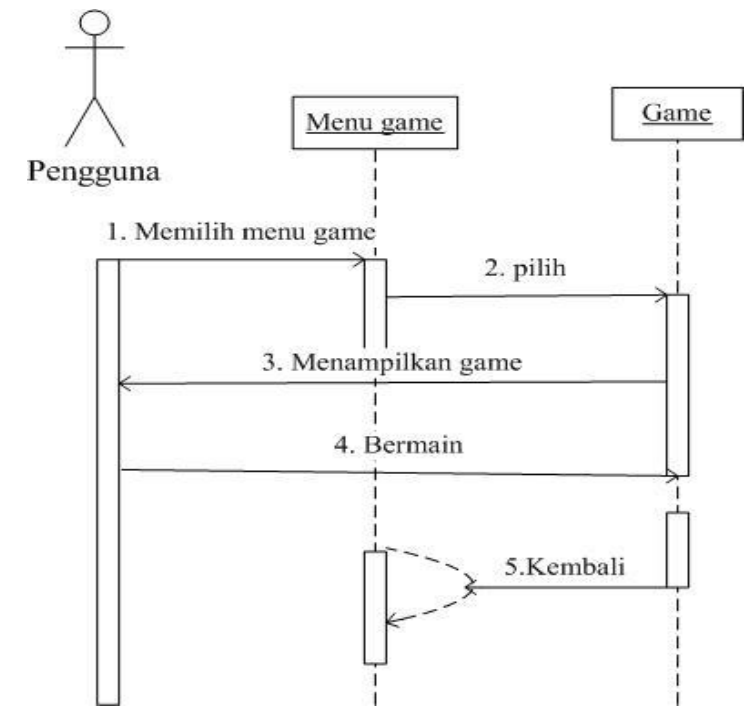

Gambar 4.5 Sequence Diagram Game
2. Sequence Diagram Latihan

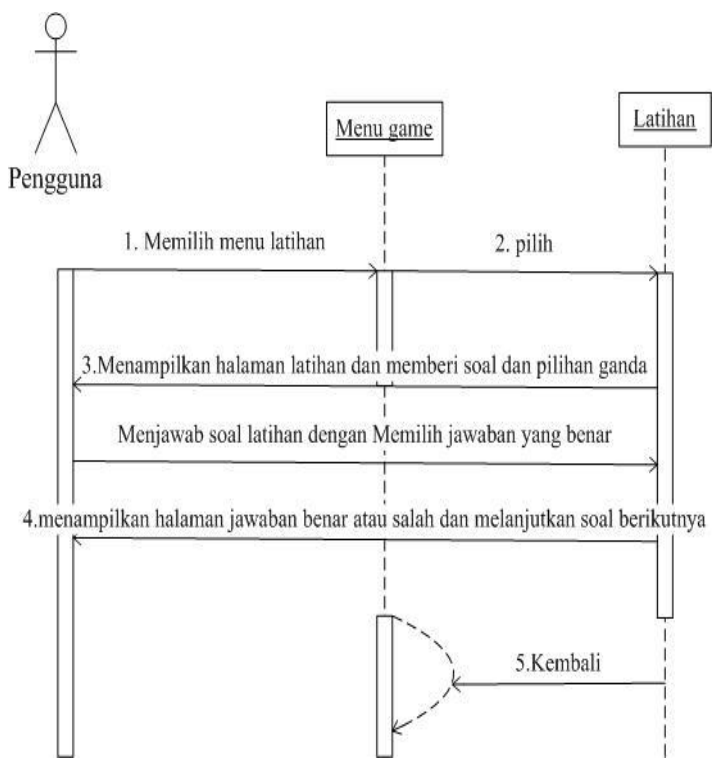

Gambar 4.6 Sequence Diagram Latihan

3. Sequence Diagram Credits

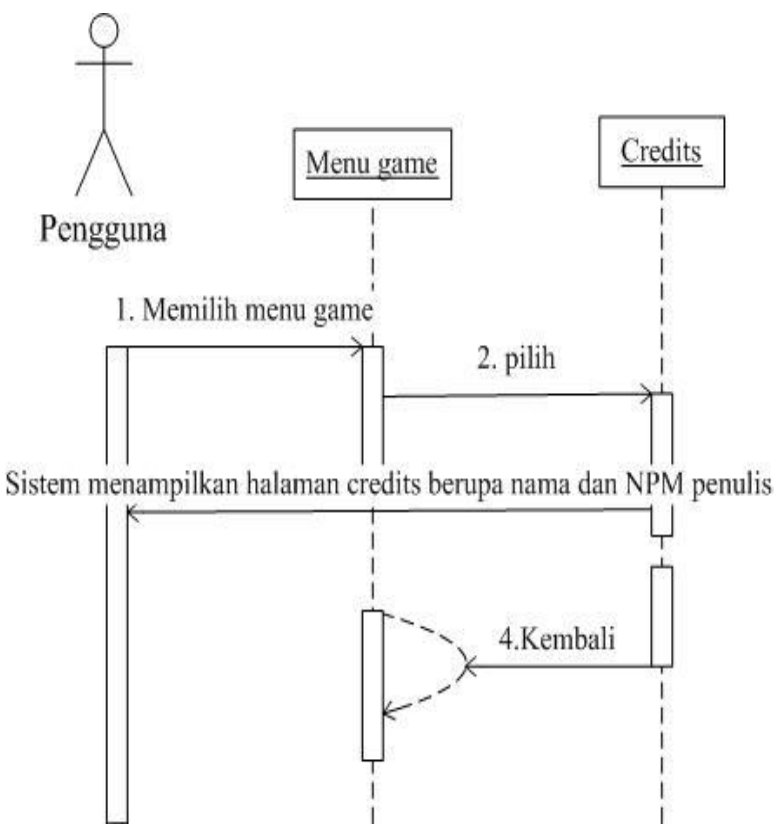

Gambar 4.7 Sequence Diagram Credits

\subsubsection{Class Diagram}

Class Diagram adalah suatu rancangan yang dapat menunjukkan hubungan antara satu kelas dengan kelas lainya dalam sistem yang sedang 
dirancang. Class Diagram juga menunjukkan struktur kelas-kelas pada sistem.

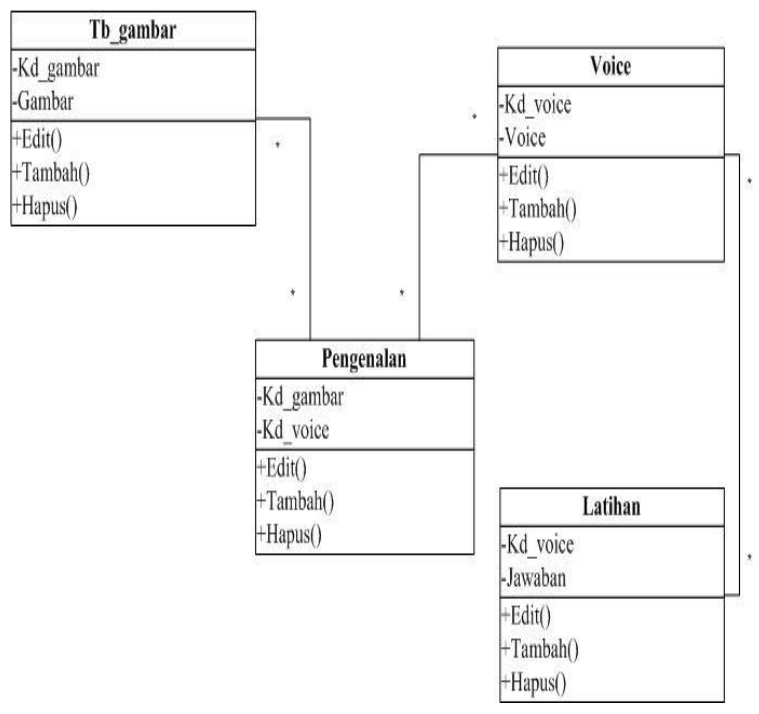

Gambar 4.8 Class Diagram Game

\subsection{Planning (Perencanaan)}

Tahap ini berguna untuk dapat mengatur kinerja para software engineer mengetahui soal resiko yang dihadapi nanti, serta mengetahui apa saja sumber daya yang dibutuhkan misalnya sumber daya manusia dan sumber daya teknologi. Sumber daya manusia meliputi analisis.

\subsubsection{Sumber Daya Manusia (SDM)}

Adalah salah satu faktor yang sangat penting bahkan tidak dapat dilepaskan dari sebuah organisasi, baik institusi maupun perusahaan. SDM juga merupakan kunci yang menentukan perkembangan perusahaan. Pada hakikatnya, SDM berupa manusia yang dipekerjakan disebuah organisasi sebagai penggerak, pemikir dan perencana untuk mencapai tujuan organisasi itu. Di aplikasi ini aktor yang meliputi pembuat dan pengguna.

1. Sumber daya alternative (pembuat) adalah sumber daya yang di desain untuk digunakan dengan konfigurasi tertentu. Untuk menetapkan bahwa satu kelompok sumber daya ditujukan bagi konfigurasi tertentu.

2. Sumber daya default (pengguna) adalah sumber daya yang harus digunakan apa pun konfigurasi perangkatnya atau jika tidak ada sumber daya alternatif yang sesuai dengan konfigurasi saat ini.

Sumber daya analisis yaitu menghasilkan apa, serta yang paling penting adalah mengatur jadwal pembuatan perangkat lunak yang efektif.

Tabel 4.6 Rencana Kegiatan

\subsection{Modeling (Pemodelan)}

Pada tahap perancangan ini penulis merancang struktur data, tampilan interface dan tujuannya untuk lebih memahami gambaran besar dari apa yang akan dikerjakan.

\begin{tabular}{|c|l|c|c|c|c|c|}
\hline \multirow{2}{*}{ No } & \multicolumn{2}{|c|}{ Kegiatan } & \multicolumn{5}{|c|}{ Bulan } \\
\cline { 3 - 6 } & & Sep & Okt & Nov & Des & Jan \\
\hline 1. & $\begin{array}{l}\text { Komunikasi } \\
\text { (Communication) }\end{array}$ & & & & & \\
\hline 2. & $\begin{array}{l}\text { Perencanaan } \\
\text { (Planning) }\end{array}$ & & & & & \\
\hline 3. & Pemodelan (Modeling) & & & & & \\
\hline 4. & $\begin{array}{l}\text { Konstruksi } \\
\text { (Contruction) }\end{array}$ & & & & & \\
\hline 5. & Uji Coba & & & & & \\
\hline 6. & $\begin{array}{l}\text { Distribution } \\
\text { (Menyebar Luaskan) }\end{array}$ & & & & & \\
\hline
\end{tabular}




\subsubsection{Desain dan Rancangan}

\subsubsection{Stuktur Aplikasi}

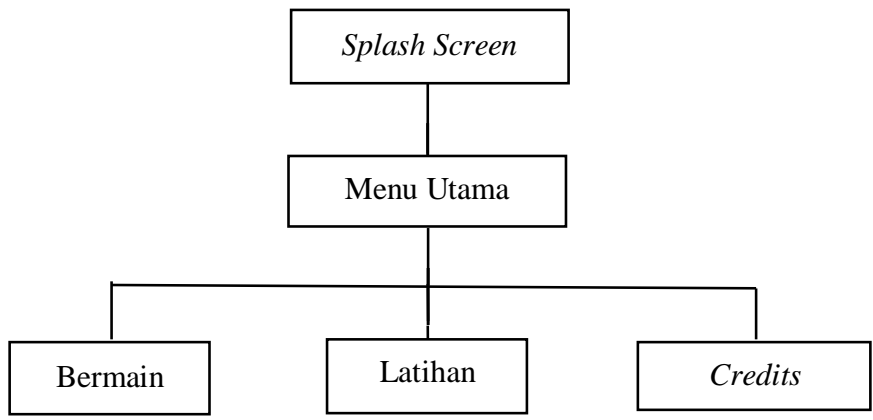

Gambar 4.9 Struktur Aplikasi

Pada struktur aplikasi dijelaskan bahwa pada aplikasi pengenalan huruf ini terdapat menu utama yaitu Bermain, Latihan, dan Credits. Jika pengguna memilih menu bermainmaka akan tampil game. Jika pengguna memilih menulatihan,maka akan tampil pertanyaan. Dan jika pengguna memilih menu Credits maka akan muncul nama dan NPM perancang aplikasi.

\subsubsection{Perancangan Pengguna Interface}

Perancangan antarmuka dilakukan untuk menentukan bentuk dan tampilan dari sistem.

1. Rancangan Menu Game

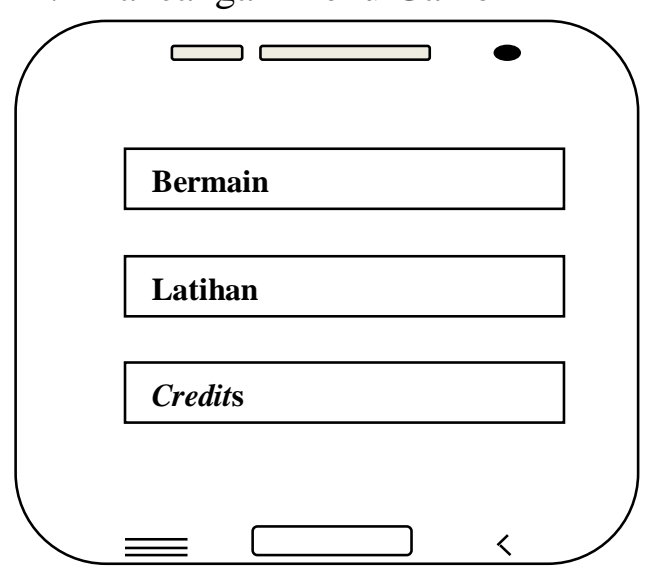

Gambar 4.10 Menu Game
- Penjelasan menu-menu dalam game

\section{Menu Bermain}

Berfungsi untuk

memulai/memainkan game.

\section{Menu Latihan}

Berfungsi untuk memberikan soal kepada pengguna berupa voice dan pilihan ganda.

\section{Menu Credits}

Berfungsi untuk menampilkan halaman credits berupa nama dan NPM penulis.

\section{Rancangan Bermain}

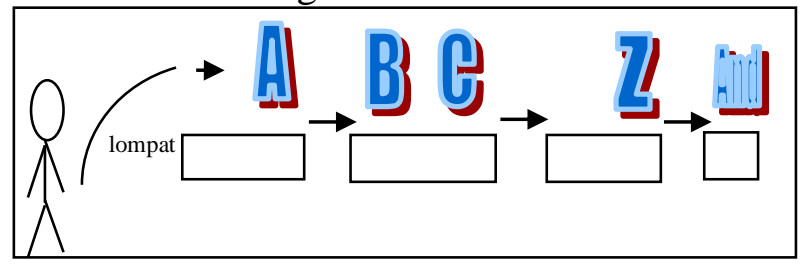

Gambar 4.11 Rancangan Bermain

3. Rancangan Latihan

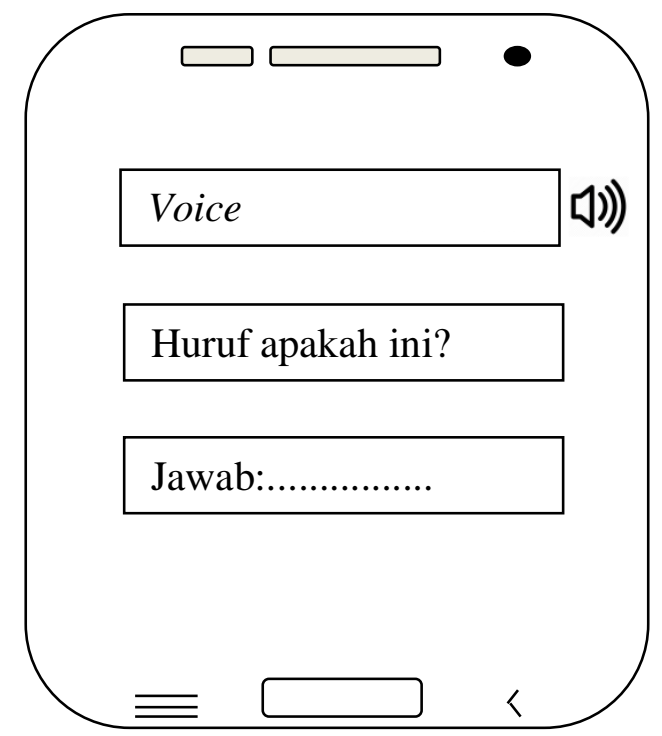


Gambar 4.12 Rancangan Latihan

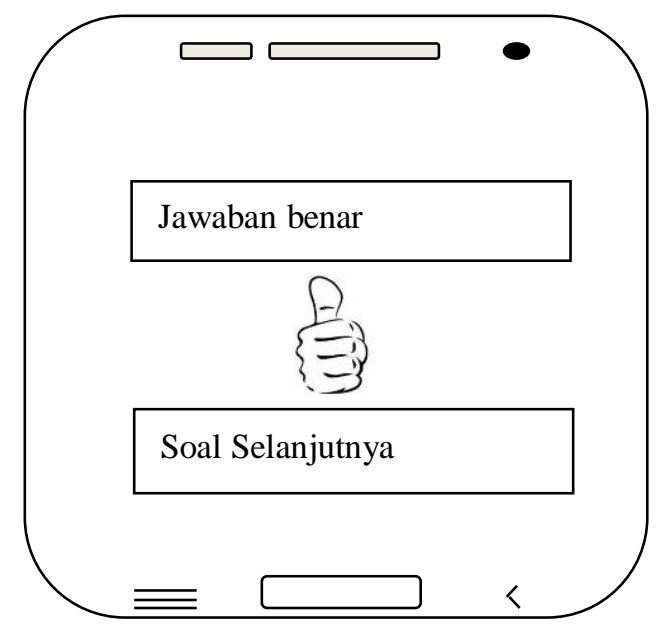

Gambar 4.13 Rancangan Jawaban Benar

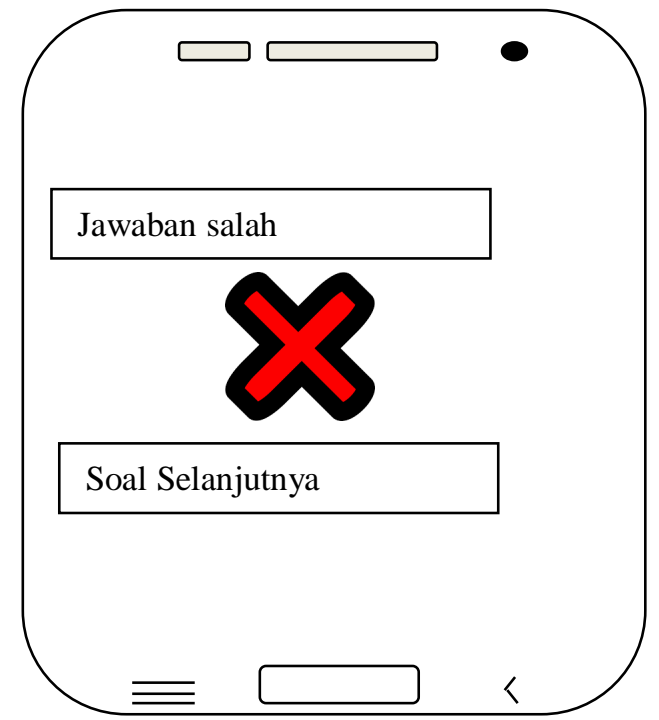

Gambar 4.14 Rancangan Jawaban Salah

\section{RancanganCredits}

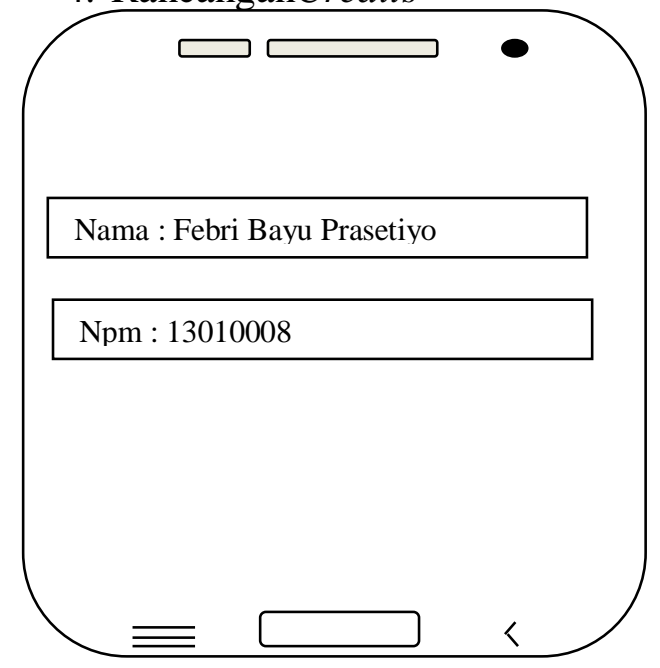

\subsection{Construction}

Pada tahap ini penulis melakukan pengkodean bahasa yang dapat dibaca oleh mesin. Tujuannya untuk menemukan kesalahan yang mungkin terjadi untuk diperbaiki.

\section{BERMAIN}

(function $(\$)\{$

// define variables

var canvas $=$

document.getElementById('canvas'); var ctx = canvas.getContext ('2d'); var player, score, stop, ticker; var ground $=[]$, water $=[]$, enemies $=$ [], huruf $=[]$, environment $=[]$; var platformHeight, platformLength, gapLength;

var platformWidth $=32$;

var platformBase $=$ canvas.height platformWidth; // bottom row of the game var platformSpacer $=64$;

\section{LATIHAN}

$<$ ?php ob_start(); ?> $<$ div role="main" class="main" $>$ $<$ div class="container"> $<\mathrm{hr}$ class="solid my-5"> $<$ div class="row justify-content-center pt-2 pb-4">

$<$ div class="col-lg-6">

$<$ h5 class $=$ "text-primary" $>$ MARI

BERLATIH, KLIK DAN

DENGARKAN! HURUF APAKAH

INI? $<$ h3 $><$ ?php echo

\$pesansalah;? $><$ ?php echo \$pesanbenar;? $></ \mathrm{h} 3\rangle\langle/ \mathrm{h} 5\rangle$ $<$ div class="col text-center" $\rangle$ $<$ div class="logo"> $<$ a href="\#"> $<$ ?php 


\section{CREDITS}

$<$ !DOCTYPE html>

$<$ html $>$

$<$ head $>$

$<$ meta charset="UTF-8">

$<$ title $>$ ABCD Runner $</$ title $>$

$<$ link rel="stylesheet" href="kandi.css"

type="text/css" media="screen" $>$

<script type="text/javascript"

src="jquery.2.1.1.min.js" $></$ script $>$

<style>

\subsection{Uji Coba}

Pada tahap uji coba ini penulis menginstall aplikasi diberbagai macam versi android. Kemudian penulis mencoba aplikasi tersebut, apakah terjadi error saat instalasi atau tidak. Jika dinyatakan sudah tidak ada bug/error lagi, maka aplikasi akan masuk ke tahap publikasi.

\subsubsection{Pengujian Black Box}

Pengujian black box dilakukan dengan memperhatikan masukan ke sistem dan keluaran dari sistem. Pengujian black box yang dilakukan adalah sebagai berikut :

1. Kasus dan Hasil Pengujian

a. Pengujian Halaman Utama

Tabel 4.7 Kasus Pengujian Halaman Utama

\begin{tabular}{|c|c|c|c|}
\hline \multicolumn{4}{|c|}{ Kasus dan Hasil Uji (Data Normal) } \\
\hline $\begin{array}{c}\text { Data } \\
\text { Masukan }\end{array}$ & $\begin{array}{c}\text { Yang } \\
\text { Diharapkan }\end{array}$ & Pengamatan & Kesimpulan \\
\hline \multirow{2}{*}{$\begin{array}{l}\text { Klik } \\
\text { "Mulai" }\end{array}$} & \multirow{2}{*}{$\begin{array}{l}\text { Permainan } \\
\text { Dimulai }\end{array}$} & \multirow{2}{*}{$\begin{array}{l}\text { Halaman bermain } \\
\text { Game berjalan }\end{array}$} & {$[\sqrt{ }]$ diterima } \\
\hline & & & [ ] ditolak \\
\hline \multirow{3}{*}{$\begin{array}{l}\text { Klik } \\
\text { "Credits" }\end{array}$} & \multirow{3}{*}{$\begin{array}{l}\text { Tampilkan } \\
\text { Halaman Data } \\
\text { Developer }\end{array}$} & \multirow{3}{*}{$\begin{array}{l}\text { Semua Data } \\
\text { Developer Tampil }\end{array}$} & {$[\sqrt{ }]$ diterima } \\
\hline & & & [] ditolak \\
\hline & & & \\
\hline
\end{tabular}

b. Pengujian Halaman Bermain
Tabel 4.8 Kasus Pengujian Halaman Bermain (Data Normal)

\begin{tabular}{|c|c|c|c|}
\hline \multicolumn{4}{|c|}{ Kasus dan Hasil Uji (Data Normal) } \\
\hline $\begin{array}{c}\text { Data } \\
\text { Masukan }\end{array}$ & $\begin{array}{c}\text { Yang } \\
\text { Diharapkan }\end{array}$ & Pengamatan & Kesimpulan \\
\hline \multirow{2}{*}{$\begin{array}{l}\text { Klik } \\
\text { "Lompat" }\end{array}$} & \multirow{2}{*}{$\begin{array}{l}\text { Karakter } \\
\text { melompat }\end{array}$} & \multirow{2}{*}{$\begin{array}{l}\text { Karakter } \\
\text { melompat sesuai } \\
\text { dengan } \\
\text { waktunya }\end{array}$} & {$[\sqrt{ }]$ diterima } \\
\hline & & & [ ] ditolak \\
\hline \multirow{3}{*}{$\begin{array}{l}\text { Ambil } \\
\text { "Huruf", }\end{array}$} & \multirow{3}{*}{$\begin{array}{l}\text { Huruf dapat } \\
\text { di lewati dan } \\
\text { terdengan } \\
\text { suara huruf }\end{array}$} & \multirow{3}{*}{$\begin{array}{l}\text { Huruf dapat di } \\
\text { lewati dan suara } \\
\text { terdengar } \\
\text { dengan baik }\end{array}$} & {$[\sqrt{ }]$ diterima } \\
\hline & & & [] ditolak \\
\hline & & & \\
\hline
\end{tabular}

\subsection{Distribution (Menyebar Luaskan)}

Pada tahap Distribution (Menyebar

Luaskan) ini penulis meng-upload aplikasi game pengenalan huruf (gameadventure)

ke playstore dengan membuat akun google play. Kemudian penulis mempromosikannya melalui media sosial kepada sekolah PAUD dan TK dengan harapan aplikasi ini dapat membantu anak-anak belajar mengenal huruf.

\subsection{Finish}

Tahapan Finishmerupakan tahapan terakhir (finishing) dalam pembuatan aplikasi ABCD runner.

Tahapan ini penulis menujukan hasil dari penelitian yang dilakukan, dan hasil dari perancangan aplikasi pembelajaran berbasis android.

\subsubsection{Tampilan Halaman Menu}

Halaman Menu merupakan halaman yang berisi menu game yaitu Mulai, latihan dan credits. Memulai berfungsi untukmemulai game $\mathrm{ABCD}$ Runner, Latihan berfungsi untuk melatih anak-anak belajar mengenal 
huruf, dan menu credits berfungsi untuk menampilkan data pembuat game.

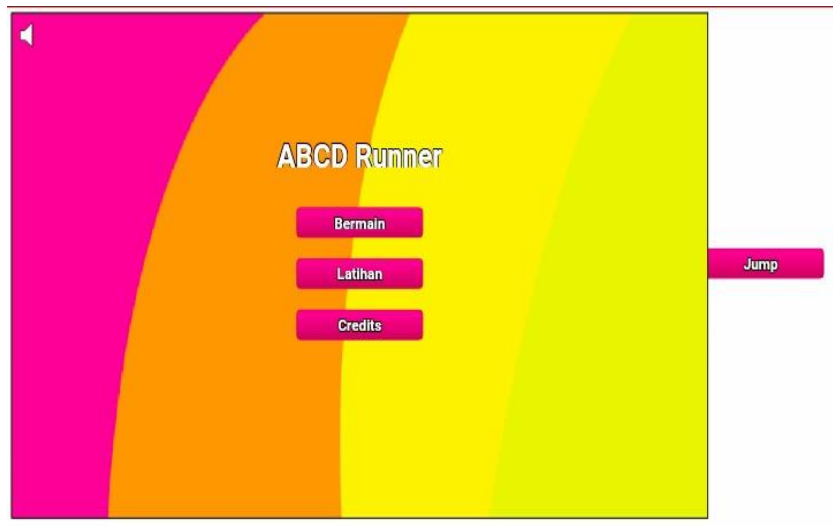

Gambar 4.16 Tampilan Halaman Menu

\subsubsection{Tampilan Halaman Game}

Form menu utama pada admin merupakan form utama yang berfungsi untuk mengelola menu-menu atau form lainnya yang terdapat di dalam aplikasi. Form menu utama akan tampil saat admin pertama kali setelah admin melakukan login. Pada saat form ini aktif, administrator dapat melakukan setting web setting menu dan memasukan info-info yang dibutuhkan untuk membuat data driver. Berikut merupakan bentuk tampilannya

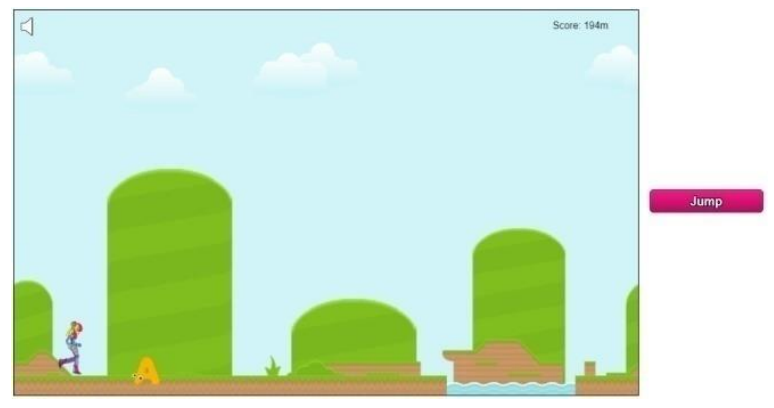

Gambar 4.17 Tampilan Halaman Bermain Game

\subsubsection{Tampilan Halaman Game Over}

Form menu utama pada admin merupakan form utama yang berfungsi untuk mengelola menu-menu atau form lainnya yang terdapat di dalam aplikasi. Form menu utama akan tampil saat admin pertama kali setelah admin melakukan login. Pada saat form ini aktif, administrator dapat melakukan setting web setting menu dan memasukan info-info yang dibutuhkan untuk membuat data driver. Berikut merupakan bentuk tampilannya

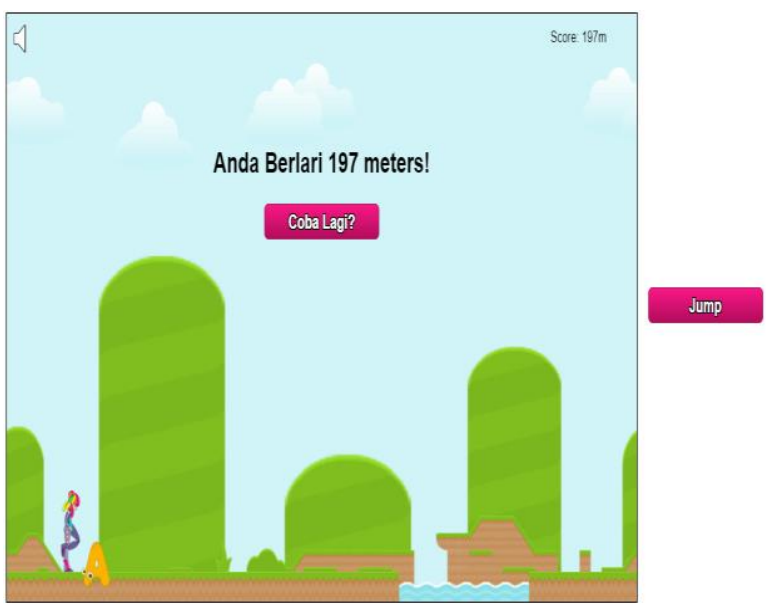

Gambar 4.18 Tampilan Halaman Game Over

\subsubsection{Tampilan Halaman Latihan}

Berikut merupakan bentuk tampilannya dari menu halaman latihan. Jawaban benar atau salah maka, akan melanjutkan soal latihan berikutnya. 


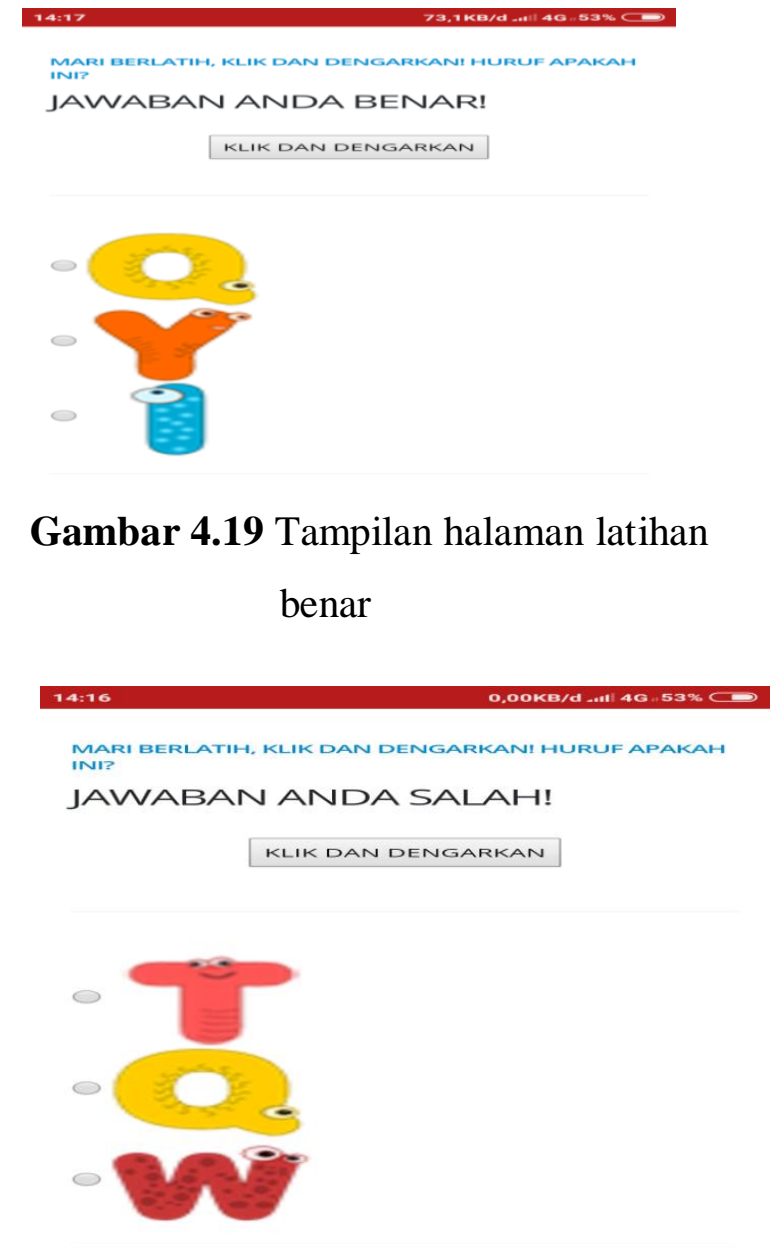

Gambar 4.20 Tampilan halaman latihan Salah

\subsubsection{Tampilan Halaman Credits}

Berikut merupakan bentuk

tampilannya dari menu halaman

credits

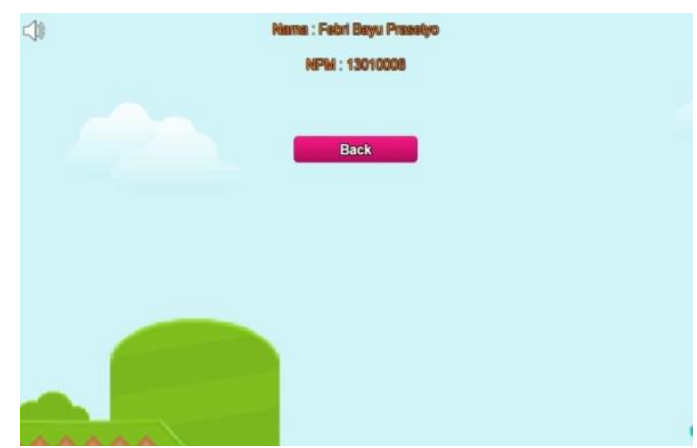

Gambar 4.21 Tampilan Halaman Credits 